JURNAL
PENELITIAN PENDIDIKAN IPA $\begin{gathered}\begin{array}{c}\text { e-ISSN : 2407-795X } \\ \text { p-ISSN : 2460-2582 }\end{array} \\ \begin{array}{c}\text { Vol 2, No, 1 } \\ \text { Januari } 2016\end{array} \\ \text { http://jurnal.unram.ac.id/index.php/jpp-ipa }\end{gathered}$

\title{
PENGARUH MODEL PEMBELAJARAN DISCOVERY DAN INKUIRI TERBIMBING BERBASIS EKSPERIMEN TERHADAP HASIL BELAJAR FISIKA DAN SIKAP ILMIAH SISWA
}

\author{
Nur Istiqamah, Aris Doyan, Muhammad Taufik \\ Program Studi Pendidikan Fisika \\ Universitas Mataram \\ Email : nur.istiqomah.fisika.11@gmail.com, arisdoyan@yahoo.co.id, taufik@unram.ac.id
}

\begin{abstract}
Key Words
discovery, guided inquiry, experiment, physics learning outcomes, and scientific attitude

$\frac{\text { Abstract }}{\text { This research is aimed to investigate the influence of discovery learning model }}$ and guided inquiry based experiment method to the physics learning outcomes and students' scientific attitude. This research is a quasi experiment with $2 \times 2$ of factorial design method. The population is all students of 13 classes of grade X of SMAN 2 Mataram. Sample is determined by using a cluster random sampling method. Data is analyzed by t-test statistics of two sample. The results showed that discovery learning model based experiment method has influence to the physics learning outcomes and students' scientific attitude, and guided inquiry learning model based experiment method has influence to the physics learning outcomes and students' scientific attitude. Beside that, discovery learning model and guided inquiry based experiment method has influence to the physics learning outcomes and students' scientific attitude.
\end{abstract}

\begin{tabular}{|c|c|}
\hline Kata Kunci & Abstrak \\
\hline $\begin{array}{l}\text { discovery, } \\
\text { inkuiri } \\
\text { terbimbing, } \\
\text { eksperimen, } \\
\text { hasil belajar } \\
\text { fisika, dan } \\
\text { sikap ilmiah }\end{array}$ & $\begin{array}{l}\text { Penelitian ini bertujuan untuk mengetahui pengaruh model pembelajaran } \\
\text { discovery dan inkuiri terbimbing berbasis eksperimen terhadap hasil belajar fisika } \\
\text { dan sikap ilmiah siswa. Jenis penelitian yang digunakan adalah quasi experiment } \\
\text { dengan bentuk desain penelitian yaitu desain faktorial } 2 \times 2 \text {. Populasi pada } \\
\text { penelitian ini adalah seluruh siswa kelas X SMAN } 2 \text { Mataram sebanyak } 13 \text { kelas. } \\
\text { Teknik pengambilan sampel yakni cluster random sampling. Teknik analisis data } \\
\text { menggunakan uji t dua sampel. Berdasarkan hasil penelitian dapat disimpulkan } \\
\text { bahwa terdapat pengaruh model pembelajaran discovery berbasis eksperimen } \\
\text { terhadap hasil belajar fisika dan sikap ilmiah siswa, dan terdapat pengaruh model } \\
\text { pembelajaran inkuiri terbimbing berbasis eksperimen terhadap hasil belajar fisika } \\
\text { dan sikap ilmiah siswa, serta terdapat pengaruh model pembelajaran discovery } \\
\text { dan inkuiri terbimbing berbasis eksperimen terhadap hasil belajar fisika dan sikap } \\
\text { ilmiah siswa }\end{array}$ \\
\hline
\end{tabular}




\section{PENDAHULUAN}

Fisika merupakan ilmu yang lahir dan berkembang lewat langkah-langkah observasi, perumusan masalah, penyusunan hipotesis, pengujian hipotesis melalui eksperimen, penarikan kesimpulan, serta penemuan teori dan konsep. Dapat dikatakan bahwa hakikat fisika adalah ilmu pengetahuan yang mempelajari gejalagejala melalui serangkaian proses yang dikenal dengan proses ilmiah yang dibangun atas dasar sikap ilmiah dan hasilnya terwujud sebagai produk ilmiah yang tersusun atas tiga komponen terpenting berupa konsep, prinsip, dan teori yang berlaku secara universal (Trianto, 2012). Hakikat fisika dalam pembelajaran yang dibangun atas dasar sikap ilmiah akan mudah dipahami jika siswa tertarik dengan pembelajaran fisika. Ketika siswa merasa tertarik dengan pembelajaran fisika, maka siswa akan semangat untuk belajar sehingga mampu menghadapi kesulitan yang menghadang dan mencapai tujuan yang diharapkan.

Berdasarkan hasil observasi peneliti melalui wawancara dengan salah seorang guru dan beberapa siswa SMAN 2 Mataram tahun ajaran 2014/2015, bahwa metode yang digunakan dalam pembelajaran fisika yaitu metode ceramah, metode diskusi, dan metode eksperimen. Namun model pembelajaran yang lebih sering digunakan adalah model pembelajaran langsung sehingga di dalam proses pembelajaran masih didominasi oleh peran aktif guru yang menyampaikan materi dan siswa hanya sebagai penerima atau bersifat pasif. Selain itu, permasalahan juga terdapat pada siswa karena beberapa siswa malas bertanya jika tidak mengerti materi yang diajarkan. Hal ini berdampak pada hasil belajar fisika siswa yang rendah.

Berdasarkan latar belakang di atas maka peneliti mencoba melakukan penelitian pembelajaran yang mengedepankan pembelajaran yang berpusat pada siswa, yakni dengan menerapkan model pembelajaran discovery dan inkuiri terbimbing berbasis eksperimen. Di dalam model pembelajaran discovery dan inkuiri terbimbing, guru bersifat sebagai fasilitator, artinya siswa yang aktif untuk menemukan suatu pemecahan dalam permasalahan fisika dan guru sebagai petunjuk jalan dan pembimbing siswa menuju pemecahan masalah tersebut sehingga diharapkan hasil belajar fisika siswa meningkat dan sikap ilmiahnya berkembang.

\section{A. Model Pembelajaran Discovery}

Model pembelajaran discovery merupakan model pembelajaran yang mengarahkan siswa untuk menemukan sesuatu melalui proses pembelajaran, pada model ini siswa dibiasakan untuk menjadi 
seorang saintis (Koasih, 2014). Melalui pembelajaran penemuan (discovery), diharapkan siswa terlibat dalam penyelidikan suatu hubungan, mengumpulkan data, dan menggunakannya untuk menemukan hukum atau prinsip yang berlaku pada kejadian tersebut (Suprihatiningrum, 2013).

Sintak model pembelajaran discovery sebagai berikut (Kurniasih, 2014):

1.Stimulation (pemberian rangsangan)

2.Problem statement (identifikasi masalah)

3.Data collection (pengumpulan data)

4.Data processing (pengolahan data)

5.Verification (pembuktian)

6.Generalization (menarik kesimpulan)

Kelebihan model ini yakni mampu membuat siswa memperoleh pengetahuan bersifat individual sehingga lebih kokoh tertanam pada jiwanya, memperkuat kepercayaan pada diri siswa dalam proses penemuan, serta membuat siswa memperoleh kesempatan untuk berkembang dan maju sesuai dengan kemampuannya (Prasetyo, 2004).

\section{B. Model Pembelajaran Inkuiri Terbimbing}

Model pembelajaran inkuiri merupakan model pembelajaran yang melibatkan kerja kolaboratif siswa sehingga masing-masing siswa dapat belajar dari siswa lain dalam sebuah interaksi sosial yang kondusif (Abidin, 2014).
Pembelajaran inkuiri terbagi menjadi tiga jenis berdasarkan besarnya intervensi guru terhadap siswa atau besarnya bimbingan yang diberikan oleh guru kepada siswanya. Ketiga macam pembelajaran inkuiri tersebut adalah inkuiri terbimbing, inkuiri bebas, dan inkuiri bebas yang dimodifikasikan. Selama proses pembelajaran inkuiri terbimbing, guru membimbing siswa melakukan kegiatan dengan memberi pertanyaan awal dan mengarahkan pada suatu diskusi. Sedangkan selama proses pembelajaran inkuiri bebas, bimbingan dari guru sangat sedikit diberikan atau bahkan tidak diberikan sama sekali, dan inkuiri bebas yang dimodifikasikan merupakan kolaborasi atau modifikasi dari inkuiri terbimbing dan inkuiri bebas (Jauhar, 2011).

Sintak model pembelajaran inkuiri sebagai berikut (Abidin, 2014):

1. Menetapkan masalah

2. Merumuskan hipotesis

3. Melaksanakan penelitian

4. Mengolah dan menganalisis data

5. Menguji hipotesis

6. Membuat kesimpulan umum

7. Menyajikan hasil

Kelebihan model ini yakni mendorong siswa untuk berpikir dan bekerja keras atas inisiatifnya sendiri, bersikap obyektif, jujur, dan terbuka, mengembangkan bakat atau kecakapan 
individu, serta mendorong siswa untuk merumuskan hipotesisnya sendiri (Roestiyah, 2012).

\section{Metode Eksperimen}

Metode eksperimen adalah cara penyajian pelajaran, yaitu siswa melakukan percobaan dengan mengalami dan membuktikan sendiri sesuatu yang dipelajari. Pembelajaran dengan menggunakan metode eksperimen mempunyai 3 langkah, yaitu persiapan, pelaksanaan, dan evaluasi/tindak lanjut eksperimen (Djamarah, 2006).

Kelebihan metode ini yakni mampu membuat siswa lebih percaya atas kebenaran atau kesimpulan berdasarkan pecobaannya sendiri dari pada hanya menerima kata guru atau membaca buku, siswa dapat mengembangkan sikap untuk mengadakan studi eksplorasi (menjelajahi) tentang ilmu dan teknologi, menumbuhakan dan membina manusia sehingga dapat membawa terobosan baru dengan penemuan hasil percobaan yang bermanfaat bagi kesejahteraan hidup manusia (Faizi, 2013).

\section{Hasil Belajar Fisika}

Hasil belajar merupakan akibat dari suatu proses belajar (Suprijono, 2012). Pada penelitian ini, hasil belajar dibatasi pada ranah kognitif yang mengacu pada taksonomi Krathwol-Anderson meliputi C1 sampai C6 (mengingat, memahami, mengaplikasi, menganalisis, mengevaluasi, dan membuat).

\section{E. Sikap Ilmiah Siswa}

Sikap ilmiah adalah sikap yang diperlihatkan oleh para ilmuwan saat siswa melakukan kegiatan sebagai seorang ilmuwan (Yuliani, 2012). Pada penelitian ini, sikap ilmiah hanya dibatasi pada dimensi sikap ingin tahu, respek terhadap data, berpikir kritis, penemuan dan kreativitas, berpikiran terbuka dan kerjasama, ketekunan, dan peka terhadap lingkungan sekitar.

\section{METODE PENELITIAN}

Penelitian ini dilaksanakan pada kelas X SMAN 2 Mataram tahun ajaran 2014/2015. Jenis penelitian ini adalah kuasi eksperimen. Desain penelitian menggunakan factorial design $2 \times 2$. Teknik pengambilan sampel yang digunakan adalah cluster random sampling. Sampel pada penelitian ini adalah siswa kelas X10 sebagai kelas eksperimen I dan siswa kelas X11 sebagai kelas eksperimen II.

Terdapat tiga variabel yang menjadi fokus penelitian yaitu variabel bebas, variabel terikat, dan variabel kontrol. Variabel bebas berupa model pembelajaran discovery dan inkuiri terbimbing berbasis eksperimen, variabel terikat berupa hasil belajar dan sikap ilmiah siswa, variabel 
kontrol berupa materi, instrumen, penilaian, waktu, dan jam pelajaran.

Teknik pengumpulan data pada penelitian ini adalah tes hasil belajar dan angket sikap ilmiah siswa. Tes berupa pilihan ganda sebanyak 29 soal dan angket sebanyak 25 pernyataan diberikan pada kedua kelas. Tes dan angket ini telah diujicobakan kepada 34 siswa kelas $\mathrm{X}$ di SMAN 2 Mataram tahun ajaran 2014/2015 dengan mengukur uji validitas, reliabilitas, tingkat kesukaran, dan daya beda. Analisis data untuk menguji hipotesis menggunakan uji t dua sampel. Peningkatan hasil belajar dan sikap ilmiah ditentukan dengan rumus uji $N$-Gain.

\section{HASIL DAN PEMBAHASAN}

Data yang diperoleh dalam penelitian berasal dari dua kelas, yaitu kelas eksperimen I dan kelas eksperimen II. Berdasarkan hasil analisis data, data keseluruhan kelas bersifat homogen dan terdistribusi normal.

Berikut ditampilkan hasil uji $\mathrm{t}$ dua sampel dengan bantuan SPSS 17.

Tabel 1. Hasil Uji t Dua Sampel

\begin{tabular}{lcc}
\hline \multicolumn{1}{c}{ Hipotesis } & Sig & Status \\
\hline (1) Model pembelajaran Discovery terhadap hasil belajar & 0,00 & $\mathrm{H}_{0}$ ditolak \\
\hline (2) Model pembelajaran Discovery terhadap sikap ilmiah & 0,00 & $\mathrm{H}_{0}$ ditolak \\
\hline (3) Model pembelajaran inkuiri terbimbing terhadap hasil belajar & 0,00 & $\mathrm{H}_{0}$ ditolak \\
\hline $\begin{array}{l}\text { (4) Model pembelajaran inkuiri terbimbing terhadap sikap ilmiah } \\
\begin{array}{l}\text { (5)Model pembelajaran Discovery dan inkuiri terbimbing terhadap hasil } \\
\text { belajar }\end{array}\end{array}$ & 0,00 & $\mathrm{H}_{0}$ ditolak \\
\hline $\begin{array}{l}\text { (6)Model pembelajaran Discovery dan inkuiri terbimbing terhadap sikap } \\
\text { ilmiah }\end{array}$ & 0,00 & $\mathrm{H}_{0}$ ditolak \\
\hline
\end{tabular}

Berdasarkan Tabel 1, didapatkan hasil bahwa nilai sig sebesar 0,00 (sig < 0,05) untuk pengujian hipotesis pertama, hipotesis kedua, hipotesis ketiga, hipotesis keempat, hipotesis kelima, dan hipotesis keenam, maka H01, H02, H03, H04, H05, H06 ditolak. Artinya: (1) terdapat pengaruh model pembelajaran discovery berbasis eksperimen terhadap hasil belajar fisika siswa, (2) terdapat pengaruh model pembelajaran discovery berbasis eksperimen terhadap sikap ilmiah siswa, (3) terdapat pengaruh model pembelajaran inkuiri terbimbing berbasis eksperimen terhadap hasil belajar fisika siswa, (4) terdapat pengaruh model pembelajaran inkuiri terbimbing berbasis eksperimen terhadap sikap ilmiah siswa, (5) terdapat pengaruh model pembelajaran discovery dan inkuiri terbimbing berbasis eksperimen terhadap hasil belajar fisika siswa, dan (6) terdapat pengaruh model pembelajaran 
discovery dan inkuiri terbimbing berbasis eksperimen terhadap sikap ilmiah siswa.

Berdasarkan analisis uji hipotesis pertama, diperoleh nilai sig sebesar 0,00 (sig $<0,05)$ sehingga hipotesis nol ditolak dan hipotesis alternatif diterima, maka terdapat pengaruh model pembelajaran discovery berbasis eksperimen terhadap hasil belajar fisika siswa. Model pembelajaran discovery merupakan model pembelajaran yang dapat mengaktifkan siswa. Model pembelajaran ini sangat cocok dipadukan dengan metode eksperimen karena ketika mereka melakukan eksperimen, maka mereka mendapat pengalaman langsung untuk ikut terlibat dalam menemukan sendiri solusi dari permasalahan yang ingin diteliti sehingga dengan menggunakan metode eksperimen, pengalaman itu akan tertanam dan menguatkan ingatan siswa tentang konsep pembelajaran fisika khususnya pada materi kalor dan berpengaruh terhadap hasil belajarnya ketika mereka diberikan tes.

Berdasarkan analisis uji hipotesis kedua, diperoleh nilai sig sebesar 0,00 (sig $<0,05)$ sehingga hipotesis nol ditolak dan hipotesis alternatif diterima, maka terdapat pengaruh model pembelajaran discovery berbasis eksperimen terhadap sikap ilmiah siswa.

Dampak positif pada sikap ilmiah siswa di kelas eksperimen I muncul karena tahap-tahap dalam model pembelajaran discovery yang dipadukan dengan metode eksperimen dapat mengembangkan sikap ilmiah siswa. Pada tahap stimulasi, siswa akan bersemangat untuk mencari jawaban atas pertanyaan yang diajukan oleh guru. Sikap jujur, ketekunan, dan tanggung jawab akan terlihat pada tahap selanjutnya, yaitu pada tahap identifikasi masalah, pengumpulan data, pengolahan data, verifikasi, dan generalisasi. Hasil penelitian ini sesuai dengan penelitian yang dilakukan oleh Widiadnyana (2014) yang menyatakan bahwa model pembelajaran discovery berpengaruh terhadap sikap ilmiah siswa.

Berdasarkan analisis uji hipotesis ketiga, diperoleh nilai sig sebesar 0,00 (sig $<0,05)$ sehingga hipotesis nol ditolak dan hipotesis alternatif diterima, maka terdapat pengaruh model pembelajaran inkuiri terbimbing berbasis eksperimen terhadap hasil belajar fisika siswa. Model pembelajaran inkuiri terbimbing merupakan model pembelajaran yang melatih siswa seperti seorang ilmuan. Melalui model pembelajaran ini, siswa mencari tahu solusi dari permasalahan tentang pembelajaran fisika layaknya seorang ilmuan. Model pembelajaran ini sangat cocok dipadukan dengan metode eksperimen karena ketika mereka melakukan eksperimen, maka mereka terlibat langsung dalam kegiatan tersebut sehingga siswa dapat menemukan solusi 
dari permasalahan yang hendak diteliti melalui metode eksperimen. Solusi tersebut akan menguatkan ingatan siswa tentang konsep pembelajaran fisika khususnya pada materi kalor.

Adanya perubahan pada hasil belajar fisika memperlihatkan bahwa penerapan model pembelajaran inkuiri terbimbing berbasis eksperimen di kelas eksperimen II memberikan pengaruh positif terhadap hasil belajar fisika siswa. Hasil penelitian ini sesuai dengan penelitian yang dilakukan oleh Maretasari (2012) yang menyatakan bahwa model pembelajaran inkuiri terbimbing berbasis laboratorium mempunyai pengaruh yang signifikan terhadap hasil belajar siswa.

Berdasarkan analisis uji hipotesis keempat, diperoleh nilai sig sebesar 0,00 $(\operatorname{sig}<0,05)$ sehingga hipotesis nol ditolak dan hipotesis alternatif diterima, maka terdapat pengaruh model pembelajaran inkuiri terbimbing berbasis eksperimen terhadap sikap ilmiah siswa.

Tahap-tahap dalam model pembelajaran inkuiri terbimbing yang dipadukan dengan metode eksperimen dapat mengembangkan sikap ilmiah siswa. Sikap ingin tahu dapat muncul pada setiap tahap model pembelajaran inkuiri terbimbing. Tahap pertama yaitu penetapan masalah, dengan menetapkan masalah yang akan diteliti sekaligus menentukan cara yang dipilihnya dalam meneliti masalah tersebut, siswa sudah termotivasi ingin mengetahui lebih banyak tentang masalah tersebut dan menyelidiki sendiri masalah yang ditetapkannya. Sikap jujur dan kerjasama antara siswa akan berkembang ketika siswa melakukan eksperimen secara berkelompok. Ketika melakukan eksperimen secara berkelompok, siswa akan berkumpul,bekerja sama dengan teman-temannya yang lain sehingga berkembanglah sikap ilmiah siswa.

Berdasarkan analisis uji hipotesis kelima, diperoleh nilai sig sebesar 0,00 (sig $<0,05)$ sehingga hipotesis nol ditolak dan hipotesis alternatif diterima, maka terdapat pengaruh model pembelajaran discovery dan inkuiri terbimbing berbasis eksperimen terhadap hasil belajar fisika siswa. Kedua model pembelajaran ini sangat cocok dipadukan dengan metode eksperimen karena ketika mereka melakukan eksperimen, mereka mendapat pengalaman langsung untuk menemukan sendiri solusi dari permasalahan yang ingin diteliti sehingga dengan menggunakan metode eksperimen, pengalaman itu akan tertanam tentang konsep pembelajaran fisika khususnya pada materi kalor dan berpengaruh terhadap hasil belajarnya.

Kedua model pembelajaran tersebut terdapat perbedaan dalam hal masalah yang dihadapkan kepada siswa, pada model pembelajaran discovery, siswanya dihadapkan kepada masalah yang 
direkayasa oleh guru, artinya permasalahan memang ditentukan oleh siswa tetapi batasan identifikasi masalahnya sudah ditetapkan oleh guru dan penyelesaian ataupun hasil dari proses pembelajaran sudah diketahui dulu oleh guru sehingga kemampuan siswa untuk berkreasi dalam penetapan serta penyelesaian masalah dalam proses pembelajaran tersebut terbatas. Akibatnya siswa hanya bisa menemukan masalah maupun solusi permasalahan dari rancangan yang telah guru tetapkan sebelumnya, meskipun rancangan tersebut hanya guru yang mengetahuinya, sehingga pengalaman belajar siswa dalam berkreasi kurang dan terbatas. Sedangkan pada model pembelajaran inkuiri terbimbing, permasalahan maupun solusi permasalahannya belum diketahui oleh guru, sehingga siswa dituntut untuk mengerahkan pikirannya untuk menetapkan masalah serta mencari solusi dari permasalahan yang telah ditetapkannya tersebut melalui eksperimen.

Berdasarkan analisis uji hipotesis keenam, diperoleh nilai sig sebesar 0,00 $($ sig $<0,05)$ sehingga hipotesis nol ditolak dan hipotesis alternatif diterima, maka terdapat pengaruh model pembelajaran discovery dan inkuiri terbimbing berbasis eksperimen terhadap sikap ilmiah siswa. Sikap ingin tahu dapat muncul pada setiap tahap model pembelajaran inkuiri terbimbing. Tahap pertama yaitu penetapan masalah, dengan menetapkan masalah yang akan diteliti sekaligus menentukan cara yang dipilihnya dalam meneliti masalah tersebut, siswa sudah termotivasi ingin mengetahui lebih banyak tentang masalah tersebut dan menyelidiki sendiri masalah yang ditetapkannya. Begitu pula pada tahap-tahap selanjutnya, yaitu merumuskan hipotesis, mengolah dan menganalisis data, menguji hipotesis, membuat kesimpulan umum, maupun saat menyajikan hasil.

Sikap respek terhadap data pada model pembelajaran inkuiri terbimbing terlihat pada tahap ketiga yaitu saat melaksanakan eksperimen dan pada tahap keempat yaitu saat mengolah dan menganalisis data. Pada tahap-tahap ini, siswa dituntut untuk bersikap jujur dan obyektif dalam menganalisis data.

Sikap berpikir kritis pada model pembelajaran inkuiri terbimbing terlihat pada tahap kedua yaitu saat merumuskan hipotesis, tahap ketiga yaitu saat melaksanakan eksperimen, tahap keempat yaitu saat mengolah dan menganalisis data, dan pada tahap kelima yaitu saat menguji hipotesis. Pada tahap ini, siswa dituntut untuk bersikap kritis dalam menguji benar atau tidaknya hipotesis.

Sikap penemuan dan kreativitas pada model pembelajaran inkuiri terbimbing terlihat pada tahap ketiga yaitu saat melaksanakan eksperimen, tahap keempat 
yaitu saat mengolah dan menganalisis data, tahap kelima yaitu saat menguji hipotesis, tahap keenam yaitu saat membuat kesimpulan umum, dan pada tahap ketujuh yaitu saat menyajikan hasil. Pada tahaptahap ini, siswa dapat mengembangkan sikap penemuan dan kreativitasnya dalam mengumpulkan, mengolah, dan menganalisis data,

Sikap berpikiran terbuka dan kerjasama pada model pembelajaran inkuiri terbimbing terlihat pada tahap ketiga yaitu saat melaksanakan eksperimen, tahap keempat yaitu saat mengolah dan menganalisis data, tahap kelima yaitu saat menguji hipotesis, tahap keenam yaitu saat membuat kesimpulan umum, dan pada tahap ketujuh yaitu saat menyajikan hasil. Pada tahap-tahap ini, siswa dapat mengembangkan sikap berpikiran terbuka dan kerjasama antara siswa yaitu ketika melaksanakan eksperimen untuk mengumpulkan, mengolah, dan menganalisis data.

Sikap ketekunan pada model pembelajaran inkuiri terbimbing terlihat pada tahap ketiga yaitu saat melaksanakan eksperimen dan pada tahap ketujuh yaitu saat menyajikan hasil. Pada tahap-tahap ini, siswa dapat mengembangkan sikap ketekunannya yaitu ketika melaksanakan eksperimen dengan sungguh-sungguh sesuai prosedur kerja sehingga diperoleh hasil yang bagus.

Sikap peka terhadap lingkungan sekitar pada model pembelajaran inkuiri terbimbing terlihat pada tahap ketiga yaitu saat melaksanakan eksperimen. Pada tahap ini, siswa dapat mengembangkan sikap peka terhadap lingkungan sekitarnya yaitu ketika menggunakan, membersihkan, dan merapikan alat dan bahan praktikum fisika saat melaksanakan eksperimen dan setelah eksperimen selesai.

Peningkatan hasil belajar dan sikap ilmiah terlihat dalam hasil uji N-Gain. Data hasil perhitungan $\mathrm{N}$-Gain hasil belajar fisika tiap sub materi kalor dapat dilihat pada tabel 2.

Tabel 2. Analisis Uji N-Gain Hasil Belajar Fisika Tiap Sub Materi Kalor

\begin{tabular}{clcc}
\hline No & \multicolumn{1}{c}{ Sub Materi kalor } & \multicolumn{2}{c}{ Nilai N-Gain (\%) } \\
\hline & & Kelas Eksperimen I & Kelas Eksperimen II \\
\hline 1 & Pengaruh Kalor pada Suhu Benda & 51.55 & 54.64 \\
\hline 2 & Pemuaian & 44.19 & 47.73 \\
\hline 3 & Perubahan Wujud Zat & 54.05 & 59.38 \\
\hline 4 & Perpindahan Kalor & 68.00 & 74.23 \\
\hline 5 & Asas Black & 45.98 & 54.88 \\
\hline
\end{tabular}


Berdasarkan nilai N-Gain yang dibandingkan kelas eksperimen II. Data di tertera pada tabel 2, terlihat bahwa nilai $\mathrm{N}-$ atas disajikan pada gambar 1. Gain pada kelas eksperimen I lebih rendah

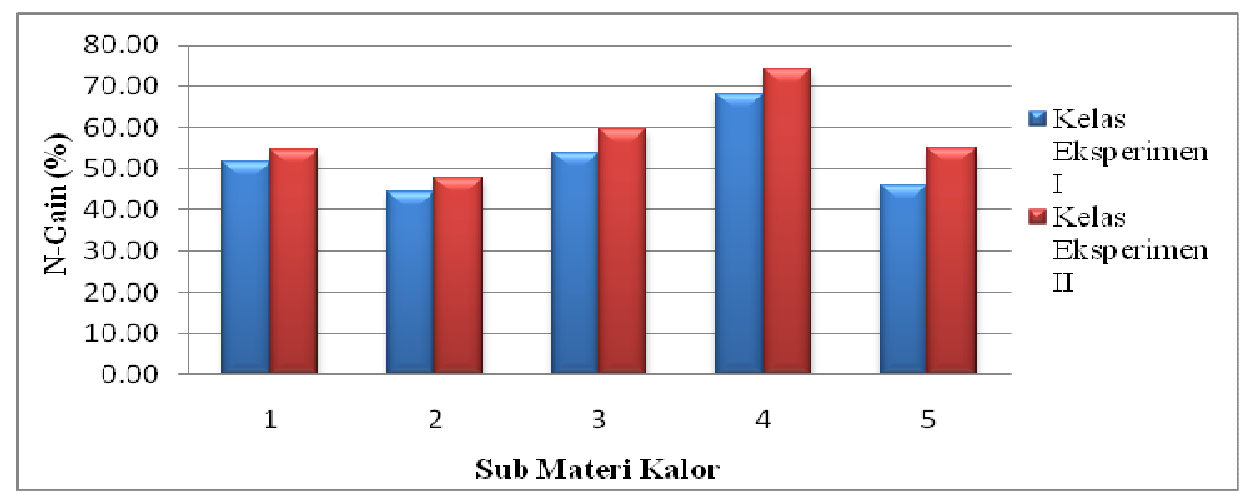

Gambar 1. Histogram Nilai N-Gain Hasil Belajar Fisika Siswa pada Tiap Sub Materi Kalor

Gambar 1 memperlihatkan bahwa nilai N-Gain hasil belajar fisika siswa yang paling tinggi berada pada sub materi kalor nomor 4 kelas eksperimen 2, yaitu perpindahan kalor. Sedangkan nilai N-Gain hasil belajar fisika siswa yang paling rendah berada pada sub materi kalor nomor 2 kelas eksperimen 1, yaitu pemuaian.

Perhitungan N-Gain sikap ilmiah siswa tiap dimensi dapat dilihat pada Tabel 3

Tabel 3. Analisis Uji N-Gain Sikap Ilmiah Siswa Tiap Dimensi

\begin{tabular}{|c|c|c|c|}
\hline \multirow{2}{*}{ No } & \multirow{2}{*}{ Dimensi Sikap Ilmiah } & \multicolumn{2}{|c|}{ Nilai N-Gain (\%) } \\
\hline & & Kelas Eksperimen I & Kelas Eksperimen II \\
\hline 1 & Sikap Ingin Tahu & 29.12 & 61.31 \\
\hline 2 & Sikap Respek Terhadap Data & 25.54 & 44.44 \\
\hline 3 & Sikap Berpikir Kritis & 21.51 & 50.43 \\
\hline 4 & Sikap Penemuan dan Kreativitas & 28.04 & 47.86 \\
\hline 5 & Sikap Berpikiran Terbuka dan Kerjasama & 26.42 & 43.96 \\
\hline 6 & Sikap Ketekunan & 25.00 & 47.06 \\
\hline 7 & Sikap Peka Terhadap Lingkungan Sekitar & 27.40 & 40.91 \\
\hline
\end{tabular}

Berdasarkan nilai N-Gain yang tertera pada tabel 3 , terlihat bahwa nilai $\mathrm{N}$ Gain pada kelas eksperimen I lebih rendah dibandingkan kelas eksperimen II untuk tiap dimensi sikap ilmiah. Data nilai NGain sikap ilmiah siswa tiap dimensi disajikan pada Gambar 2. 


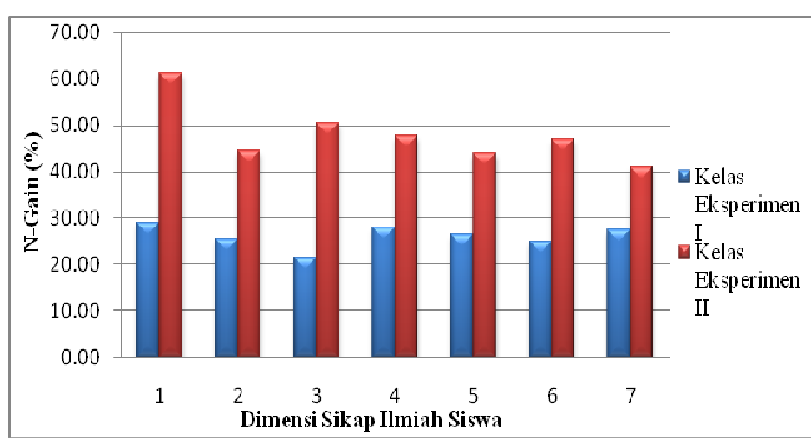

Gambar 2. Histogram Nilai N-Gain Sikap

Ilmiah Siswa pada Tiap Dimensi

Gambar 2 memperlihatkan bahwa

nilai N-Gain sikap ilmiah siswa yang paling tinggi berada pada dimensi sikap ilmiah nomor 1 kelas eksperimen II, yaitu sikap ingin tahu. Sedangkan nilai N-Gain sikap ilmiah siswa yang paling rendah berada pada dimensi sikap ilmiah nomor 3 kelas eksperimen 1, yaitu berpikir kritis.

\section{KESIMPULAN}

Penelitian ini menghasilkan temuan, bahwa model pembelajaran discovery dan inkuiri terbimbing berbasis eksperimen berpengaruh terhadap hasil belajar fisika dan sikap ilmiah siswa. Secara lebih rinci dapat diuraikan sebagai berikut: (1) terdapat pengaruh model pembelajaran discovery berbasis eksperimen terhadap hasil belajar fisika siswa, (2) terdapat pengaruh model pembelajaran discovery berbasis eksperimen terhadap sikap ilmiah siswa, (3) terdapat pengaruh model pembelajaran inkuiri terbimbing berbasis eksperimen terhadap hasil belajar fisika siswa, (4) terdapat pengaruh model pembelajaran inkuiri terbimbing berbasis eksperimen terhadap sikap ilmiah siswa, (5) terdapat pengaruh model pembelajaran discovery dan inkuiri terbimbing berbasis eksperimen terhadap hasil belajar fisika siswa, dan (6) terdapat pengaruh model pembelajaran discovery dan inkuiri terbimbing berbasis eksperimen terhadap sikap ilmiah siswa.

\section{DAFTAR PUSTAKA}

Abidin, Y. 2014. Desain Pembelajaran dalam Konteks Kurikulum 2013. Bandung: PT Refika Aditama.

Djamarah, S.B dan Zain, A. 2006. Strategi Belajar Mengajar. Jakarta: PT Rineka Cipta.

Faizi, M. 2013. Ragam Metode Mengajarkan Eksakta pada Murid. Yogyakarta: DIVA press.

Jauhar, M. 2011. Implementasi Paikem dari Behavioristik Sampai

Konstruktivistik. Jakarta: Prestasi Pustaka.

Koasih, E. 2014. Strategi Belajar dan Pembelajaran. Bandung: Yrama Widya.

Kurniasih, I dan Sani, B. 2014. Sukses Mengimplementasikan Kurikulum 2013. Yogyakarta: Kata Pena.

Maretasari, E. 2012. Penerapan Model Pembelajaran Inkuiri Terbimbing Berbasis Laboratorium untuk Meningkatkan Hasil Belajar dan Sikap Ilmiah Siswa. Unnes Physics Education Journal. Universitas Negeri Semarang. 
Prasetyo, Z. 2004. Kapita Selekta Pembelajaran Fisika. Jakarta: Universitas Terbuka.

Roestiyah. 2012. Strategi Belajar Mengajar. Jakarta: PT Rineka Cipta.

Suprihatiningrum, J. 2013 Strategi Pembelajaran Teori dan Aplikasi. Yogyakarta: Ar-ruz Media.

Suprijono, A. 2012. Cooperative Learning Teori dan Aplikasi Paikem. Yogyakarta: Pustaka Pelajar.

Trianto. 2012. Model Pembelajaran Terpadu: Konsep, Strategi, dan Implementasinya dalam KTSP. Jakarta: Bumi Aksara.

Widiadnyana. 2014. Pengaruh Model Discovery Learning Terhadap Pemahaman Konsep IPA dan Sikap Ilmiah Siswa SMP. Jurnal Program Pascasarjana Program Studi IPA. Universitas Pendidikan Ganesha.

Yuliani, H. 2012. Pembelajaran Fisika dengan Pendekatan Keterampilan Proses dengan Metode Eksperimen dan Demonstrasi Ditinjau dari Sikap Ilmiah dan Kemampuan Analisis. Jurnal Inkuiri. Universitas Sebelas Maret. 